\title{
New records of Uroderma magnirostrum Davis (Mammalia, Chiroptera) from southeastern Brazil, with comments on its natural history
}

\author{
Marcelo R. Nogueira ${ }^{1}$, Valéria C. Tavares ${ }^{2} \&$ Adriano L. Peracchi ${ }^{1}$
}

1 Programa de Pós-graduação em Biologia Animal, Departamento de Biologia Animal, Instituto de Biologia, Universidade Federal Rural do Rio de Janeiro. 23890-000 Seropédica, Rio de Janeiro, Brasil.

E-mail: mrnogueira@rionet.com.br; aperacchi@webdigital.com.br

2 Department of Mammalogy, American Museum of Natural History. Central Park West at 79 ${ }^{\text {th }}$ Street, New York, NY, 10024.

E-mail: tavares@amnh.org

\begin{abstract}
Uroderma magnirostrum Davis, 1968 is reported from four new localities in southeastern Brazil, significantly extending its geographical distribution south and westward. A total of 12 adult specimens collected in areas of Caatinga and Atlantic Forest in the states of Minas Gerais, Espírito Santo, and Rio de Janeiro, including specimens from the new localities and museum specimens were examined. Females from southeastern Brazil were larger than males in all external measurements analyzed, but after univariate statistical analyses using corrected $\mathrm{p}$ values for multiple tests no significant sexual dimorphism was detected. Mean values obtained from this sample fall within the known range documented for the species in both external and cranial measurements, and are similar to those found in specimens from north and northeastern Brazil. The habitats of the new localities of $U$. magnirostrum in southeastern Brazil ranged from pristine and secondary forests to a small urban park. Uroderma magnirostrum is apparently a rare species in southeast Brazil, which corroborates most previous reports of populations of this bat at other localities.
\end{abstract}

KEY WORDS. Stenodermatinae, distribution, habits, morphological measurement analysis.

Uroderma magnirostrum Davis, 1968 is a medium-sized stenodermatine bat that occurs from Mexico to the southeast coastal Brazil (Koopman 1993, Peracchi \& Albuquerque 1993). Although widely distributed, this bat seems to be locally rare (Willig 1983, OchoA et al. 1988, Woodman et al. 1991, AgUirRe et al. 1996, Kalko et al. 1996, Lim \& Engstrom 2001) and little is known about its biology. Uroderma magnirostrum is often associated with humid lowland areas and seems to exhibit some plasticity in its environmental tolerances, occurring in yards, pastures, orchards, and croplands (HANDLEY 1976). Although HANDLEY (1976) captured U. magnirostrum in elevations ranging from 1 to 1,140 $\mathrm{m}$ in Venezuela, most of the captures occurred below $500 \mathrm{~m}$ of altitude. Uroderma magnirostrum is recognized as a tent-making bat species, roosting under modified palm leaves (Timm 1987, Kunz \& LuMSDEN 2003). According to GARDNER (1977), this bat is primarily frugivorous, a feeding habit that has been corroborated by the scarce data subsequently obtained (Reis \& Peracchi 1987, Ascorra \& Wilson 1992, Ascorra et al. 1996, MuÑoz-SABA et al. 1997).

Most records of $U$. magnirostrum in Brazil are from localities within the Amazonian Forest biome (DAVIs 1968, ReIs \& Schubart 1979, Taddei \& Reis 1980, Peracchi et al. 1984, Marques 1985, Reis \& Peracchi 1987, Taddei et al. 1990, Voss \& Emmons
1996, Nogueira et al. 1999, Bernard 2001, Bernard \& Fenton 2002). Few additional records are known from localities in the Cerrado biome (Pine et al. 1970), Caatinga (Mares et al. 1981, Willig \& Mares 1989), and Atlantic Forest (Peracchi \& AlbuQUERque 1993). Specimens captured by Peracchi \& Albuquerque (1993) in the state of Espírito Santo, in the north part of the Brazilian southeastern, represent the southernmost record of U. magnirostrum registered to date.

Here new records of $U$. magnirostrum in areas of Caatinga and Atlantic Forest in southeastern Brazil are reported, and the known range of the species is extended south and westward. New information on the biology of the species, along with mensural data and a discussion of characters that allow for the correct identification of $U$. magnirostrum are also provided.

\section{MATERIAL AND METHODS}

All specimens of $U$. magnirostrum reported here were captured with ground-level mist-nets and are deposited in the following institutions: the Adriano Lúcio Peracchi collection (ALP) at the Instituto de Biologia, Universidade Federal Rural do Rio de Janeiro, state of Rio de Janeiro, and the Laboratory of Chiropterology, in the Universidade para o Desenvolvimento do

Revista Brasileira de Zoologia 20 (4): 691-697, dezembro 2003 
Estado e da Região do Pantanal (UNIDERP), Campo Grande, state of Mato Grosso do Sul. In addition to the material from new localities, specimens from the series reported by PERACCHI \& Albuquerque (1993) and from Acre state, northern Brazil, were also examined. Only adult specimens (with phalangeal epiphyses and basisphenoid region completely ossified) were included in the analyzes. Measurements were taken with calipers precise to $0.05 \mathrm{~mm}$ and generally following the protocol described by TADDEI \& UIEDA (2001). The exceptions were that greatest skull length and mandibular length were measured not including the incisors, and that tibia length (from the proximal end of the tibia to the posterior base of the calcar) was included in the list of measurements. Secondary sexual dimorphism for $U$. magnirostrum in southeastern Brazil was tested using independent $t$-tests with sequential Bonferroni correction for multiple comparisons (Rice 1989). To minimize the loss of power associated to this correction, the experiment-wise error rate was stated at $10 \%$ as suggested by CHANDLER (1995). This procedure led to an initial alfa value of 0.006 ( $0.10 / 16$ variables). Prior to $t$-tests, all variables were examined for homogeneity of variances by Levene tests. When this assumption was not met (e.g., greatest skull length), a $t$-test with separate variance estimates was applied. Statistical analyses were performed using the program STATISTICA 5.0 for Windows (STATSOFT 1995).

Abbreviations used in tables are as follows: forearm length (FA), tibia length (TIL), third metacarpal length (MEIII), fourth metacarpal length (MEIV), fifth metacarpal length (MEV), greatest length of skull (GLS), condylocanine length (CCL), postorbital breath (POB), zygomatic breath (ZYG), braincase breath (BCB), mastoid breath (MTB), mandibular length (MBL), maxillary toothrow length (MTL), mandibular toothrow length $(\mathrm{MNT})$, breath across molars (BAM), breath across canines (BAC).

Specimens examined (9 males, 5 females): Acre: Taumaturgo, Parque Nacional da Serra do Divisor, Igarapé Paratari (ALP 7179); Rodrigues Alves, Igarapé Grande (ALP 7340); MinAs GeraIs: Jaíba (ALP 6831, 6833, 6834); Marliéria, Parque Estadual do Rio Doce (UNIDERP uncataloged); EsPírito SANTO: Linhares, Mata dos Goitacazes (ALP 1648, 2149, 2807, 3012); Linhares, Reserva Florestal da Companhia Vale do Rio Doce (ALP 3942); RIO DE JANEIRO: Rio de Janeiro, Jardim Botânico do Rio de Janeiro (ALP 8163); Rio de Janeiro, Parque Arruda Câmara (ALP 6029, 6033).

\section{RESULTS}

Four new localities were recorded for U. magnirostrum in southeastern Brazil (Fig. 1). Four individuals were captured by the first author (MRN) in a limestone outcrop known as "Morro Solto" (ca. $15^{\circ} 15^{\prime} \mathrm{S}, 43^{\circ} 51^{\prime} \mathrm{W}$; $c a .510 \mathrm{~m}$ elevation), in the municipality of Jaíba, in the extreme northern part of Minas Gerais state and the southern limit of the Caatinga biome. Crevices and cavities are abundant at this site, which is also characterized by the presence of a hyper-xerophytic caatinga formation and some mesophytic plants such as Cecropia Loefling (Cecropiaceae) and Ficus Linnaeus (Moraceae). Two adult males of $U$. magnirostrum were captured in April $6^{\text {th }}, 1994$ and two additional specimens, an adult male (left testis $5 \times 3.9 \mathrm{~mm}$ ) and a lactating female, were captured in the following night at 1930 and 2015 hours, respectively. Local relative frequency of U. magnirostrum in the sample from Morro Solto was $2 \%$ (four individuals in a sample of 210 bats).

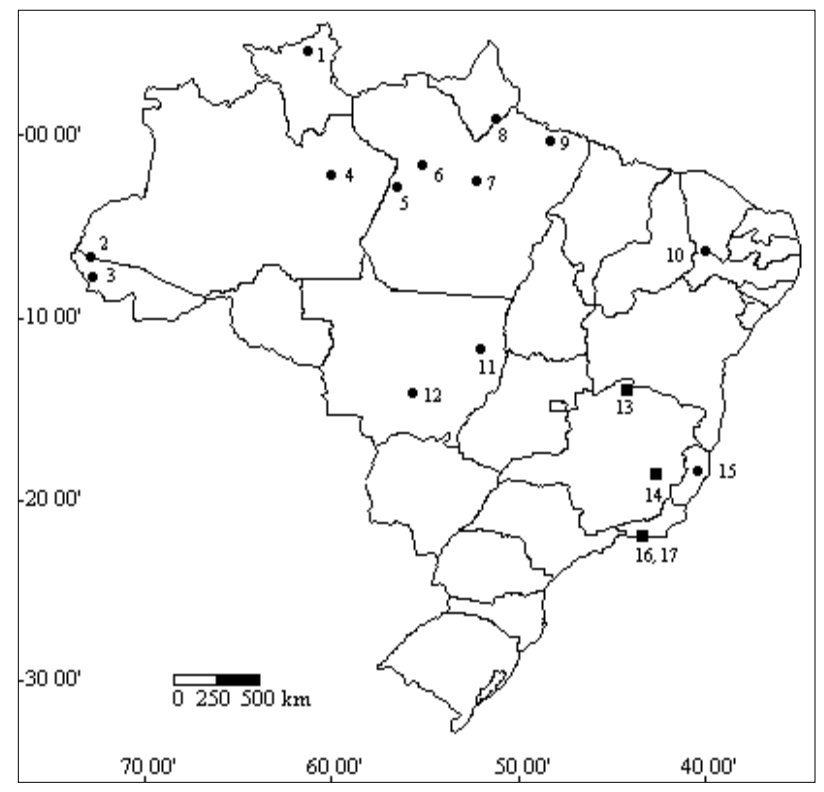

Figure 1. Locality records for Uroderma magnirostrum in the Brazilian territory. Squares represent new localities. (1) Maracá, (2) Cruzeiro do Sul, (3) Parque Nacional da Serra do Divisor, (4) Manaus, (5 Parque Nacional da Amazônia, (6) Boim, (7) Lower Rio Xingu, (8) Macapá, (9) Belém, (10) Chapada do Araripe, (11) Xavantina, (12) Chapada dos Guimarães, (13) Jaíba, (14) Parque Estadual do Rio Doce, (15) Linhares, (16) Parque Arruda Câmara, (17) Jardim Botânico do Rio de Janeiro.

In eastern Minas Gerais state, municipality of Marliéria, the second author (VT) captured a single individual of $U$. magnirostrum in the Parque Estadual do Rio Doce $\left(19^{\circ} 29^{\prime}\right.$ and $19^{\circ} 48^{\prime} \mathrm{S}, 42^{\circ} 28^{\prime} \mathrm{W}$; 230 to $515 \mathrm{~m}$ elevation). This is the largest preserved area of Atlantic Forest in Minas Gerais (ca. 36,000 ha) and one of the largest in the Brazilian southeast. The specimen was a pregnant female weighing 23 grams, captured in October $1^{\text {st }}, 1997$ in a trail inside the area known as "Campolina", which is the most preserved tract of forest within the Parque. Uroderma magnirostrum represented $1.8 \%$ of the 54 bats captured at the Campolina area and $0.6 \%$ of the total of 179 bats recorded in the Parque Estadual do Rio Doce.

The two additional records of $U$. magnirostrum were from the mid-southern part of the state of Rio de Janeiro, in the municipality of Rio de Janeiro. At 2300 h on August $17^{\text {th }}, 1998$, the first author (MRN) captured a single specimen at the Jardim Botânico do Rio de Janeiro ( $22^{\circ} 58^{\prime} 14^{\prime \prime} \mathrm{S}, 4^{\circ} 13^{\prime} 18^{\prime \prime} \mathrm{W} ; 3 \mathrm{~m}$ elevation). This adult male (left testis $3.6 \times 3.3 \mathrm{~mm}$ ) weighed $14 \mathrm{~g}$ and was netted in the border of a secondary Atlantic Forest that is contiguous with the arboretum of Jardim Botânico and that extends westward into the Parque Nacional da Tijuca $(3,300 \mathrm{ha})$, the largest urban natural park in the world. A seed of Ficus sp. was found in the fecal sample of this specimen that accounted for only $0.04 \%$ of the captures at this site ( 1 individual in a sample of 2,407 bats).

The Parque Arruda Câmara $\left(22^{\circ} 59^{\prime} 48^{\prime \prime}\right.$ S, $43^{\circ} 22^{\prime} 37^{\prime \prime}$ W; $12 \mathrm{~m}$ elevation) is a 50 ha area $16 \mathrm{~km}$ apart from the Jardim 
Botânico do Rio de Janeiro and covered mainly by restinga vegetation. The lowland region ("Baixada de Jacarepaguá") where this park is located has a long history of intense human disturbance and is currently composed mostly by urban areas and anthropic fields (grasslands). The two specimens available from this site, an adult male and an adult female, were collected by Adriana M. Marques in April 1999 and May 1999, respectively. The records from Parque Estadual do Rio Doce and Parque Arruda Câmara extend the previous southernmost record of U. magnirostrum (Linhares, Espírito Santo state) 257 $\mathrm{km}$ westward and $525 \mathrm{~km}$ southward, respectively (Fig. 1). Uroderma magnirostrum has not been recorded in the states of Minas Gerais and Rio de Janeiro prior to our study.

Mensural data from 12 specimens of $U$. magnirostrum from southeastern Brazil, including measurements of seven specimens from the new localities are summarized in table I. Females averaged larger than males in all five external measurements analyzed but the opposite was found in 10 of the 12 skull variables. After the sequential Bonferroni correction, however, none of the measurements were significantly dimorphic. Mean values of external and cranial measurements reported here for U. magnirostrum from southeastern Brazil are also similar to the values for specimens from northern and northeastern Brazil and fall within the known range documented for the species (Tab. II). Individual measurements of some specimens fall out of this range, but the extent of this variation seems to be small, ranging from 0.15 (MNT) to $0.35 \mathrm{~mm}$ (MXT) in males, and reaching $0.4 \mathrm{~mm}$ in females (BC).

\section{DISCUSSION}

Regarding discrete diagnostic features, specimens of $U$. magnirostrum from southeastern Brazil followed the general pattern described from northern South American populations in: pale or yellowish-brown to grayish brown pelage, facial and malar white stripes poorly developed or absent, presence of a faint dorsal stripe (from neck to rump), and ear pinna concolor or with a whitish edging. These characters sharply contrast with that observed in Uroderma bilobatum Peters, 1866, the congeneric species that is found in sympatry with $U$. magnirostrum in Southeastern Brazil. In U. bilobatum the dorsal stripe and both upper and lower facial stripes are bright white, and the ear pinna presents a well-defined yellowish or whitish edge (DAvIs 1968, ReID 1997). Three other discrete characters identified by DAvIS (1968) proved to be useful to distinguish $U$. magnirostrum from U. bilobatum. The rostral profile in the former species gently slopes from the anterior portion of the braincase (forehead) to the anterior facial premaxillae, the rostrum is robust, deep and heavy, and the mesethmoid is laterally expanded, assuming a shield-like appearance. In contrast, the rostral profile in $U$. bilobatum is disrupted by the angle formed by the forehead and the rostral bones, anterior facial maxilla and premaxillae are depressed in frontal view, and the mesethmoid is narrow.

Little is known on the biology of $U$. magnirostrum, and information on food preferences, habitat use, and reproduction of this bat are scanty in the literature. GARDNER (1977) reported that several individuals captured in Peru were dusted with pollen, suggesting a previous feeding on flower products. In Peru this bat is known to feed on the fruits of Ficus (Ascorra et al. 1996), as reported here for southeastern Brazil, as well as Photomorphe peltata Miq. (Piperaceae) (Ascorra \& Wilson 1992).
Reis \& Peracchi (1987) found seeds of Cecropia palmata Willd. in the feces of a single specimen from the Brazilian Amazon. From a collection of nine specimens from the Serranía La Macarena, Colombia, MUÑOZ-SABA et al. (1997) reported for $U$. magnirostrum a diet composed $78 \%$ by fruits, $11 \%$ by nectar and pollen, and $11 \%$ by insects. Regarding the first food item, these authors also mentioned that fruits of diversified species were consumed by U. magnirostrum, suggesting some flexibility in the use of this resource.

The presence of $U$. magnirostrum in both pristine and disturbed areas in southeastern Brazil corroborates previous data suggesting relative plasticity in environmental tolerances for this bat (HandeEy 1976). The use of disturbed areas by $U$. magnirostrum may be correlated with feeding on plants that are gap specialists (e.g. Cecropia spp.). Reis \& Peracchi (1987) captured this bat in a very disturbed secondary forest in the Brazilian Amazon, and ReIs (pers. comm.) associated this fact with the use of Cecropia fruits and the abundance of this tree in his study site. Species of Cecropia, however, are known to occur at all new sites from which U. magnirostrum is reported, including the well-preserved Campolina area and the Morro Solto outcrop. Also in these areas, therefore, Cecropia may prove to be an important food resource for $U$. magnirostrum. Fruits of Cecropia are widely used by fruit-eating bats (Orozco-Segovia \& VÁsquez-Yanes 1982, Charles-Dominique 1986, Zórtea \& Chiarello 1994, Rомо 1996, Passos et al. 2003) and have shown to be a core resource for these mammals in certain areas (FLEMING 1986).

Uroderma magnirostrum has generally been considered a rare species (WiLlig 1983, KaLKO et al. 1996), a conclusion also supported by the data from southeastern Brazil. In Serranía La Macarena (Colombia), however, this bat was shown to be relatively more abundant, at least during part of the year (MuNozSABA et al. 1997). Although no specimen was captured in the rainy season or during the transitional period to the dry season, the relative frequency of capture of $U$. magnirostrum achieved 7\% (2 bats in a sample of 27) in the dry season and $12 \%$ (9 in 76) in the beginning of the rainy season. MuÑoz$\mathrm{S}_{\mathrm{ABA}}$ et al. (1997) suggested that this fluctuation in the relative frequency of capture of $U$. magnirostrum is correlated with seasonal fluctuation of the food resources used by this bat. PAssos et al. (2003) suggested a similar situation regarding the capture of other fruit-eating bats in the Parque Estadual Intervales, southeastern Brazil. In this area, the absence of captures of Artibeus Leach, 1821 in the cold months seems to be related to the absence of Cecropia fruits (its main food resource in the area) during this period. It is also noteworthy that in Alter do Chão, Pará (central Amazon), U. magnirostrum was the thirteenth most frequently captured bat (59 individuals) in a list of 70 species reported by Bernard \& Fenton (2002). The relative frequency of capture of $U$. magnirostrum in that area $(1.5 \%)$, however, was lower then that found in the Morro Solto outcrop (2\%). Because in southeastern Brazil the same technique (ground-level nets) employed by MuÑoz-SABA et al. (1997) was used, and at least three of the four new localities reported here were sampled during distinct seasons for at least one year, it seems that sampling bias was not a major factor determining the low frequencies recorded.

Discussions on the rarity in mammals have taken into account biological characteristics such as local population density, range of distribution, and flexibility in habitat use (YU \& Dobson 2000). As previously reported, U. magnirostrum has a large geographical distribution and had been sampled in a wide 
Table I. External and cranial measurements of U. magnirostrum from southeastern Brazil, and levels of probability for sexual differences after independent two-tailed t tests.

\begin{tabular}{|c|c|c|c|c|c|c|c|c|c|c|c|c|c|c|c|c|c|}
\hline Specimen & State & FA & TIB & $3 \mathrm{ME}$ & $4 \mathrm{ME}$ & $5 \mathrm{ME}$ & GLS & CCA & POS & ZIG & $B C$ & MAS & MAN & MXT & MNT & BAM & BAC \\
\hline \multicolumn{18}{|l|}{ Males } \\
\hline 6029 & $\mathrm{RJ}$ & 41.75 & 15.00 & 41.35 & 41.00 & 41,40 & 23.30 & 21.30 & 5.90 & 12.30 & 9.20 & 11.00 & 15.70 & 8.25 & 8.85 & 8.85 & 5.50 \\
\hline 8163 & $\mathrm{RJ}$ & 43.30 & 17.00 & 42.10 & 41.60 & 42.80 & 24.10 & 20.90 & 6.00 & 13.40 & 10.20 & 10.95 & 16.20 & 8.20 & 8.95 & 9.55 & 5.90 \\
\hline 1648 & ES & 41.40 & 15.50 & 42.55 & 40.75 & 41.80 & 22.75 & 20.20 & 5.85 & 11.65 & 9.25 & 10.65 & 15.00 & 7.95 & 8.60 & 8.55 & 5.45 \\
\hline 3942 & ES & 42.30 & 15.00 & 42.35 & 41.45 & 41.35 & 24.10 & 21.80 & 5.70 & 12.90 & 9.50 & 11.15 & 16.35 & 8.65 & 9.10 & 9.10 & 5.90 \\
\hline 6831 & MG & 42.40 & - & - & - & - & 23.25 & 21.05 & 5.60 & 12.70 & 9.70 & 10.90 & 15.75 & 8.10 & 8.70 & 8.80 & 5.60 \\
\hline 6834 & MG & 41.60 & 15.05 & 42.30 & 41.60 & 41.90 & 23.21 & 20.50 & 5.60 & 12.70 & 9.35 & 10.75 & 15.65 & 8.35 & 8.80 & 8.80 & 5.70 \\
\hline Mean & & 42.31 & 15.37 & 42.34 & 41.31 & 41.85 & 23.54 & 21.04 & 5.82 & 12.72 & 9.54 & 10.94 & 15.81 & 8.26 & 8.89 & 8.94 & 5.71 \\
\hline $\pm S D$ & & 0.80 & 0.84 & 0.66 & 0.35 & 0.52 & 0.54 & 0.56 & 0.20 & 0.62 & 0.34 & 0.20 & 0.44 & 0.22 & 0.23 & 0.35 & 0.20 \\
\hline 6033 & $\mathrm{RJ}$ & 43.40 & - & 43.90 & 41.60 & 42.40 & 23.20 & 20.70 & 5.60 & 12.70 & 9.65 & 11.10 & 15.20 & 8.05 & 8.60 & 9.00 & 5.55 \\
\hline 2149 & ES & 43.40 & 16.10 & 43.50 & 41.90 & 42.50 & 22.80 & 20.30 & 5.75 & 12.75 & 9.35 & 10.70 & 15.20 & 8.00 & 8.70 & 9.10 & 5.40 \\
\hline 2807 & ES & 43.15 & 14.20 & 42.25 & 40.60 & 41.40 & 23.25 & 20.80 & 5.90 & 13.00 & 9.55 & 10.80 & 15.55 & 8.4 & 9.10 & 9.35 & 5.65 \\
\hline 6835 & MG & 44.35 & 15.50 & 42.50 & 40.70 & 41.10 & 22.80 & 20.80 & 5.50 & 12.25 & 9.00 & 10.80 & 15.75 & 8.35 & 9.05 & 9.10 & 5.70 \\
\hline Uncataloged & MG & 44.10 & 17.00 & 44.70 & 43.40 & 43.40 & 22.90 & 20.50 & 5.70 & - & 9.50 & 11.20 & 15.30 & 8.00 & 8.90 & 9.00 & 5.60 \\
\hline Mean & & 43.68 & 15.70 & 43.37 & 41.64 & 42.16 & 22.99 & 20.62 & 5.69 & 12.67 & 9.41 & 10.92 & 15.40 & 8.16 & 8.87 & 9.11 & 5.58 \\
\hline$\pm \mathrm{SD}$ & & 0.52 & 1.17 & 1.01 & 1.13 & 0.92 & 0.22 & 0.22 & 0.15 & 0.31 & 0.25 & 0.22 & 0.24 & 0.20 & 0.22 & 0.14 & 0.12 \\
\hline$p$ & & 0.007 & 0.613 & 0.073 & 0.510 & 0.500 & 0.042 & 0.149 & 0.239 & 0.893 & 0.481 & 0.854 & 0.094 & 0.449 & 0.864 & 0.338 & 0.227 \\
\hline
\end{tabular}

variety of habitat types. Population densities, however, seem to be low across most of the distribution of this bat, regardless of the type of habitat studied. Current evidence suggests that $U$. magnirostrum does not have diet specializations, which may explain the occurrence of this bat in diversified habitats. Its roost requirements, however, remain virtually unknown. The only published record was provided by Tімм (1987), who reported the use of tents constructed in leaves of Astrocaryum murumuru Mart. (Arecaceae). Astrocarium aculeatissimum (Schott) Burret is an abundant species in the PERD. Although it was not found direct evidence of the use of this palm by $U$. magnirostrum in the Campolina forest, palm leaves with marks of bites along the axis were present in this area, which should be further investigated. Like other types of roosts (e.g., tree cavities; Kunz \& Lumsden 2003), plants suitable for manufacturing tents may constitute a limiting resource for bats (STONER 2000, Fenton et al. 2001), and their availability may prove to be an important factor influencing local abundance of $U$. magnirostrum.

WILSON (1979) suggested a polyestrous reproductive pattern for $U$. magnirostrum, which was confirmed by MARQUES (1985) based on the collection of simultaneously pregnant and lactating females in central Amazonian Brazil. MARques (1985) suggested that poliestry in U. magnirostrum is bimodal. In Peru, the reproduction of this bat seems to be concentrated in the wet season (Graham 1987). The present records (a lactating fe- male in northern Minas Gerais in April, end of the rainy season at Jaíba, and a pregnant female in eastern Minas Gerais in October, beginning of rainy season at Parque Estadual do Rio Doce) are consistent with this association between reproduction and the rainy season, but additional data, from both northern and eastern Minas Gerais state, are necessary to test for a possible correlation.

Secondary sexual dimorphism in U. magnirostrum has not been addressed to date. DAvis (1968) treated males and females separately. However, in spite of the fact that mean values of forearm length and third metacarpal length were considerably larger in the latter group, he did not comment on a possible dimorphism in size. Anderson (1997) published combined measurements of female and male Bolivian specimens. Although the comparative analysis presented here failed in finding statistically significant results, the marginal $p$ value obtained for the length of the forearm (0.007) reinforces the necessity of an increase in the sample size so that the tests could be more powerful. It is noteworthy that the usefulness of Bonferroni adjustments is not a consensus among researchers (e.g. Perneger 1998; Spraduing et al. 2001) and it has been argued that the increase in the likelihood of type II errors (failing in recognizing true differences) and the dependence of the interpretation of a finding on the number of other tests performed, make the use of this correction "unnecessary and, at worst, deleterious to sound statistical inference" (Perneger 1998: 
Table II. Selected external and cranial measurements (mean and range) of U. magnirostrum from southeastern Brazil (SE; present study), northeastern Brazil (NE; WIயIG 1983)' ${ }^{1}$, northern Brazil (NO; unpublished data from Acre state, plus measurements from TADDEI \& REIS 1980 and TADDEl et al. 1990), and from a general sample (northern Brazil and Bolivia to southern Mexico) reported by DAVIS (1968).

\begin{tabular}{|c|c|c|c|c|c|c|c|c|}
\hline \multirow[b]{2}{*}{ Character } & \multicolumn{4}{|c|}{ Males } & \multicolumn{4}{|c|}{ Females } \\
\hline & SE & NE & $\mathrm{NO}$ & General & SE & $\mathrm{NE}$ & $\mathrm{NO}$ & General \\
\hline \multirow{2}{*}{ FA } & 42.3 & - & 43.13 & 42.10 & 43.75 & - & 42.77 & 43.30 \\
\hline & $(41.4-43.4) 7$ & & $(42.95-43.3) 2$ & $(36-43.8) 22$ & $(43.15-44.35) 5$ & & $(40.7-44) 3$ & $(41-46.6) 36$ \\
\hline \multirow{2}{*}{ TIB } & 15.40 & - & 14.90 & - & 15.70 & - & 16.20 & - \\
\hline & $(14.65-17) 6$ & & $(14.3-15.5) 2$ & & $(14.2-17) 4$ & & $(15.9-16.5) 2$ & \\
\hline \multirow{2}{*}{$3 \mathrm{ME}$} & 42.30 & - & 42.63 & 41.90 & 43.24 & - & 42.37 & 42.80 \\
\hline & $(41.35-43.4) 6$ & & $(42.1-43.15) 2$ & $(35-43.7) 21$ & $(42.25-44.7) 5$ & & $(39.6-44) 3$ & $(40.5-45.5) 39$ \\
\hline \multirow{2}{*}{ 4ME } & 41.30 & - & 41.07 & - & 41.65 & - & 41.37 & - \\
\hline & $(40.75-41.6) 6$ & & $(40.75-41.4) 2$ & & $(40.6-43.4) 5$ & & $(39.1-42.6) 3$ & \\
\hline \multirow{2}{*}{$5 \mathrm{ME}$} & 41.90 & - & 42.00 & - & 42.10 & - & 41.93 & - \\
\hline & $(41.35-42.8) 6$ & & $(41.4-42.6) 2$ & & $(41.1-43.4) 5$ & & $(39.7-43.1) 3$ & \\
\hline \multirow{2}{*}{ CCA } & 21.00 & - & 20.38 & - & 20.60 & - & 20.80 & - \\
\hline & $(20.2-21.8) 7$ & & $(20.35-20.4) 2$ & & $(20.3-20.8) 5$ & & & \\
\hline \multirow{2}{*}{ POS } & 5.80 & 6.1 & 5.65 & - & 5.71 & 5.83 & 5.47 & - \\
\hline & $(5.6-6.1) 7$ & & $(5.6-5.7) 2$ & & $(5.5-5.9) 5$ & $(5.7-5.9) 3$ & $(5.2-5.6) 3$ & \\
\hline \multirow{2}{*}{ ZIG } & 12.70 & 12.5 & 12.33 & 12.70 & 12.67 & 12.73 & 12.77 & 12.70 \\
\hline & $(11.7-13.4) 7$ & & $(12.25-12.4) 2$ & $(12-13.5) 24$ & $(12.3-13) 4$ & $(12.4-13) 3$ & $(12.4-13.4) 3$ & $(12.1-13.2) 50$ \\
\hline \multirow{2}{*}{$B C$} & 9.50 & 9.7 & 9.23 & 9.70 & 9.35 & 9.53 & 9.80 & 9.80 \\
\hline & $(9.2-10.2) 7$ & & $(9.1-9.35) 2$ & $(9-10) 25$ & $(9-9.65) 5$ & $(9.4-9.7) 3$ & & $(9.4-10.3) 50$ \\
\hline \multirow{2}{*}{ MAS } & 10.90 & - & 10.93 & - & 10.88 & - & 10.77 & - \\
\hline & $(10.65-11.2) 7$ & & $(10.9-10.95) 2$ & & $(10.7-11.2) 5$ & & $(10.5-11.1) 3$ & \\
\hline \multirow{2}{*}{ MAN } & 15.80 & - & 15.43 & - & 15.45 & - & 14.87 & - \\
\hline & $(15-16.4) 7$ & & $(15.35-15.5) 2$ & & $(15.2-15.8) 5$ & & $(14.2-15.7) 3$ & \\
\hline \multirow{2}{*}{ MXT } & 8.30 & - & 7.90 & 8.00 & 8.16 & - & 7.93 & 8.00 \\
\hline & $(7.95-8.65) 7$ & & $(7.8-8) 2$ & $(7.7-8.3) 25$ & $(7.9-8.4) 5$ & & $(7.5-8.3) 3$ & $(7.5-8.5) 50$ \\
\hline \multirow{2}{*}{ MNT } & 8.90 & - & 8.53 & 8.60 & 8.94 & - & 8.90 & 8.6 \\
\hline & $(8.6-9.25) 7$ & & $(8.45-8.6) 2$ & $(8.2-9.1) 25$ & $(8.6-9.1) 5$ & & & $(8-9.1) 47$ \\
\hline \multirow{2}{*}{ BAM } & 8.90 & - & 8.70 & 8,90 & 9.14 & - & 8.83 & 9.00 \\
\hline & $(8.55-9.55) 7$ & & $(8.6-8.8) 2$ & $(8.5-9.3) 26$ & $(9-9.35) 5$ & & $(8.4-9.2) 3$ & $(8.4-9.5) 50$ \\
\hline \multirow[b]{2}{*}{ BAC } & 5.70 & - & 5.53 & - & 5.59 & - & 5.70 & - \\
\hline & $(5.45-5.9) 7$ & & $(5.5-5.55) 2$ & & $(5.4-5.7) 5$ & & & \\
\hline
\end{tabular}

${ }^{1}$ Some characters used by this author were not included in the analysis due to differences in the measurement protocol.

1236). Although in the present paper a more conservative approach has been adopted, the presentation of the respective $p$ value obtained for each comparison allows alternative interpretations of our results.

In the original description of $U$. magnirostrum, DAvIS (1968) studied 82 specimens from various localities in South and Central America, including Brazilian specimens from Pará. In contrast to data reported in the same paper for U. bilobatum, DAvIs (1968) found little evidence of geographic variation in U. magnirostrum. DAVIS (1968) argued that if the largest available sample (36 specimens from Bolivia) were excluded from the analysis, two geographic areas of differentiation could be 
discernible: Peru and northeastern Brazil, characterized by larger specimens, and Colombia, Venezuela and Middle America, by smaller ones. The range of variation found in the Bolivian material, however, was nearly identical to that observed in the entire population sample, and he considered sample sizes from areas other than Bolivia insufficient for a meaningful statistical treatment. After the study of DAVIS (1968) data on $U$. magnirostrum remained scarce and are restrict to publications with mensural data (SwanePoel \& GenowaYs 1979, Taddei \& Reis 1980, Willig 1983, Polaco \& Muñiz-Martínez 1987, TADDEI et al. 1990, ANDERSON 1997). The quantitative analysis presented here showed little variation among populations of $U$. magnirostrum, supporting the conclusion of previous studies that $U$. magnirostrum is a regionally widespread species. However, the conclusions must be taken with caution since they are limited by the low number of specimens examined. Further examination of a larger number of specimens throughout all the range of $U$. magnirostrum is needed to clarify aspects of geographical variation in this species.

\section{ACKNOWLEDGEMENTS}

We are thankful to R.P. Anderson, F.C. Passos and N.R. dos Reis for suggestions and comments on late drafts of this manuscript, to L.R. Monteiro for statistical advisory, to A. Pol for helping with the map creation, and to the many persons and institutions that have provided support to our fieldwork. M.R. Nogueira was assisted by F.M. Costa in Jaíba, and by C.P.H. Rocha in the Jardim Botânico do Rio de Janeiro. In the former area M.R. Nogueira worked under the support of SYTEC 3 Engenharia e Controle de Corrosão LTDA. V.C. Tavares had the assistance of S. Romanova, F. Perini, A. Azevedo, M. Marcos, R. Franca and R. Redondo during fieldwork in PERD. The Instituto Estadual de Florestas, through C.M. Valle, and the Instituto de Pesquisas Jardim Botânico do Rio de Janeiro, through C. Valente, N. Marquete, L.C. Giordano and N. Alves, gave permission for our fieldwork in the Parque Estadual do Rio Doce and Jardim Botânico do Rio de Janeiro, respectively. We also would like to extend special thanks to V.A. Taddei for the kind examination of the specimen under his care. All authors received financial support from Conselho Nacional de Desenvolvimento Científico e Tecnológico (CNPq).

\section{REFERENCES}

Aguirre, L.F.; W. Hanagarth \& R.J. de Urioste. 1996. Mamíferos del refugio de Vida Silvestre Espíritu, Dpto. Beni, Bolivia. Ecologia en Bolivia, La Paz, 28: 29-44.

Anderson, S. 1997. Mammals of Bolivia, taxonomy and distribution. Bulletin of the American Museum of Natural History, New York, 231: 1-652.

Ascorra, C.F. \& D.E. Wilson. 1992. Bat frugivory and seed dispersal in the Amazon, Loreto, Peru. Publicaciones del Museo de Historia Natural Universidad Nacional Mayor de San Marcos (A), Lima, 43: 1-6.

Ascorra, C.F.; D.E. Wilson \& S. Solari T. 1996. Diversidad y ecología de los quirópteros en Pakitza, p. 593-612. In: D.E. WILSON \& A. SANDOVAL (Eds). Manu: the biodiversity of southeastern Peru. Washington, D.C., Smithsonian Institution Press, 679p.

Bernard, E. 2001. Species list of bats (Mammalia, Chiroptera) of Santarém area, Pará State, Brazil. Revista Brasileira de Zoologia, Curitiba, 18 (2): 455-463.

Bernard, E. \& M.B. Fenton. 2002. Species diversity of bats (Mammalia: Chiroptera) in forest fragments, primary forests, and savannas in central Amazonia, Brazil. Canadian Journal of Zoology, Ottawa, 80: 1124-1140.

Chandler, C.D. 1995. Practical considerations in the use of simultaneous inference for multiple testes. Animal Behaviour, London, 49: 524-527.

Charles-Dominique, P. 1986. Inter-relations between frugivorous vertebrates and pioneer plants: Cecropia, birds and bats in French Guyana, p. 119-135. In: A. Estrada \& T.H. Fleming (Eds). Frugivores and seed dispersal. Dordrecht, Dr W. Junk Publishers, XII+392p.

DAvis, W.B. 1968. Review of the genus Uroderma (Chiroptera). Journal of Mammalogy, Lawrence, 49 (4): 676-698.

Fenton, M.B.; E. Bernard; S. BOUChard; L. HOllis; D.S Johnston; C.L. Lausen; J.M. Ratcliffe; D.K. Riskin; J.R. Taylor \& J. Zigouris. 2001. The bat fauna of Lamanai, Belize: roosts and trophic roles. Journal of Tropical Ecology, Cambridge, 17: 511-524.

FLEMING, T.H. 1986. Opportunism versus specialization: the evolution of feeding strategies in frugivorous bats, p. 105118. In: A. Estrada \& T.H. Fleming (Eds). Frugivores and seed dispersal. Dordrecht, Netherlands, Dr W. Junk Publishers, XII+392p.

Gardner, A.L. 1977. Feeding habits, p. 293-350. In: R.J. BAKER, J.K. Jones JR. \& D.C. CarTer (Eds). Biology of bats of the New World family Phyllostomatidae, Part II. Special Publications, Museum Texas Tech University, Lubbock, 13: 1-364.

Graham, G.L. 1987. Seasonality of reproduction in Peruvian bats. Fieldiana Zoology, New Series, Chicago, 39: 173-186.

Handeey JR., C.O. 1976. Mammals of the Smithsonian Venezuelan project. Brigham Young University Science Bulletin, Biological Series, Provo, 20 (5): 1-91.

Kalko, E.K.V.; C.O. Handley Jr. \& D. Handley. 1996. Organization, diversity, and long-term dynamics of a Neotropical bat community, p. 503-553. In: M.L. Cody \& J.A. SMallwood (Eds). Long-term studies of vertebrate communities. San Diego, Academic Press, 597p.

Koopman, K.F. 1993. Order Chiroptera, p. 137-241. In: D.E. WILSON \& D.M. REEDER (Eds). Mammal species of the world: a taxonomic and geographic reference. Washington, D.C., Smithsonian Institution Press, $2^{\text {nd }}$ ed., XVIII+1206p.

Kunz, T.H. \& L.F. LumsDen. 2003. Ecology of Cavity and Foliage Roosting Bats, p. 3-89. In: T.H. Kunz \& M.B. Fenton (Eds). Bat Ecology. Chicago, University Press, XIX+704p.

Lim, B.K. \& M.D. Engstrom. 2001. Species diversity of bats (Mammalia: Chiroptera) in Iwokrama Forest, Guyana, and the Guianan subregion: implications for conservation. Biodiversity and Conservation, London, 10: 613-657.

Mares, M.A.; M.R Willig; K.E. Streilein \& J.R. Lacher. 1981. The mammals of northeastern Brazil: a preliminary assessment. Annals of the Carnegie Museum, Pittsburgh, 50: 81-137.

Marques, S.A. 1985. Novos registros de morcegos do Parque Nacional da Amazônia (Tapajós), com observações do período de atividade noturna e reprodução. Boletim do Museu Paraense Emílio Goeldi, Nova Série, Zoologia, Belém, 2 (1): 71-83. 
Muñoz-Saba, Y.; A. Cadena \& J.O. Rangel. 1997. Ecología de los murciélagos antófilos del sector La Curia, Serraína La Macarena (Colombia). Revista de la Academia Colombiana de Ciencias Exactas, Fisicas y Naturales, Bogotá, 21 (81): 473-486.

Nogueira, M.R.; A. Pol \& A.L. Peracchi. 1999. New records of bats from Brazil with a list of additional species for the chiropteran fauna of the state of Acre, western Amazon basin (Mammalia, Chiroptera). Mammalia, Paris, 63 (3): 363-368.

Ochoa, G., J.; H.J. SAnchez; M. Bevilaceua \& R. Rivero. 1988. Inventario de los mamíferos de la Reserva Forestal de Ticoporo y la Serranía de Los Pijiguaos, Venezuela. Acta Cientifica Venezoelana, Caracas, 39 (3): 269-280.

Orozco-Segovia, A. \& C. Vazeuez-Yanes. 1982. Plants and fruit bat interactions in a tropical rain forest area, southeastern Mexico. Brenesia, San Jose, 19/20: 137-149.

Passos, F.C; W.R. Silva; W.A. Pedro \& M.R. Bonin. 2003. Frugivoria em morcegos (Mammalia, Chiroptera) no Parque Estadual Intervales, sudeste do Brasil. Revista Brasileira de Zoologia, Curitiba, 20 (3): 511-517.

Peracchi, A.L.; D.L.R. Sansão \& A.M. Tannure. 1984. Quirópteros do Território Federal do Amapá, Brasil (Mammalia, Chiroptera). Arquivos da Universidade Federal Rural do Rio de Janeiro, Seropédica, 7 (2): 89-100.

Peracchi, A.L. \& S.T. Albuquerque. 1993. Quirópteros do município de Linhares, Estado do Espírito Santo, Brasil (Mammalia, Chiroptera). Revista Brasileira de Biologia, Rio de Janeiro, 53: 575-581.

Perneger, T.V. 1998. What's wrong with Bonferroni adjustments. British Medical Journal, Edinburgh, 316: 1236-1238.

Pine, R.H.; I.R. Bishop \& R.L. Jackson. 1970. Preliminary list of mammals of the Xavantina/Cachimbo expedition (Central Brazil). Transactions of the Royal Society of Tropical Medicine and Hygiene, London, 64 (5): 668-670.

Polaco, O.J. \& R. Muñiz-Martínez. 1987. Los murciélagos de la Costa de Michoacán, México. Anales de la Escuela Nacional de Ciencias Biologicas, Mexico, 31: 63-89.

ReID, F.A. 1997. A field guide to the mammals of Central America and Southeast Mexico. New York, Oxford University Press, 334p.

ReIs, N.R. \& H.O.R. Schubart. 1979. Notas preliminares sobre os morcegos do Parque Nacional da Amazônia (médio Tapajós). Acta Amazonica, Manaus, 9 (3): 507-515.

Reis, N.R. \& A.L. Peracchi. 1987. Quirópteros da região de Manaus, Amazonas, Brasil (Mammalia, Chiroptera). Boletim do Museu Paraense Emílio Goeldi, Nova Série, Zoologia, Belém, 3: 161-182.

RICE, W.R. 1989. Analysing tables of statistical tests. Evolution, Boulder, 43 (1): 223-225.

Roмo, M.C. 1996. Seasonal variation in fruit consumption and seed dispersal by canopy bats (Artibeus spp.) in a lowland forest in Peru. Vida Silvestre Neotropical, Washington, 5 (2): 110-119.

Spradling, T.A.; M.S. Hafner \& J.W. Demastes. 2001. Differences in rate of cytochrome- $b$ evolution among species of rodents. Journal of Mammalogy, Lawrence, 82 (1): 65-80.

StaTSOFt, Inc. 1995. STATISTICA for Windows. Tulsa. [Computer program manual]

Stoner, K.E. 2000. Leaf selection by the tent-making bat Artibeus watsoni in Asterogyne martiana palms in southwestern Costa Rica. Journal of Tropical Ecology, Cambridge, 16: 151157.

Swanepoel, P. \& H.H. Genoways. 1979. Morphometrics, p. 13106. In: R.J. BaKer; J.K. Jones JR. \& D.C. Carter (Eds). Biology of bats of the New World family Phyllostomatidae. Part III. Special Publications, Museum Texas Tech University, Lubbock, 16: 1-441.

TADDEI, V.A. \& N.R. Dos ReIs. 1980. Notas sobre alguns morcegos da ilha de Maracá, Território Federal de Roraima (Mammalia, Chiroptera). Acta Amazonica, Manaus, 10 (2): 363-368.

TAdDeI, V.A.; I.M. De Rezende \& D. Camora. 1990. Notas sobre uma coleção de morcegos de Cruzeiro do Sul, Rio Juruá, Estado do Acre (Mammalia, Chiroptera). Boletim do Museu Paraense Emílio Goeldi, Nova Série, Zoologia, Belém, 6 (1): 75-88

TADDEI, V.A. \& W. UiEdA. 2001. Distribution and morphometrics of Natalus stramineus from South America (Chiroptera, Natalidae). Iheringia, Série Zoologia, Porto Alegre, 91: 123132.

Timm, R.M. 1987. Tent construction by bats of the genera Artibeus and Uroderma. Fieldiana Zoology, New Series, Chicago, 39: 187-212.

Voss, R.S. \& L.H. Emmons. 1996. Mammalian diversity in neotropical lowland rainforests: a preliminary assessment. Bulletin of the American Museum of Natural History, New York, 230: 1-115.

WilLIG, M.R. 1983. Composition, microgeographic variation, and sexual dimorphism in Caatingas and Cerrado bat communities from northeast Brazil. Bulletin of the Carnegie Museum of Natural History, Pittsburgh, 23: 1-131.

Willig, M.R. \& M.A. MAREs. 1989. Mammals from the caatinga: an updated list and summary of recent research. Revista Brasileira de Biologia, Rio de Janeiro, 49 (2): 361-367.

WILSON, D.E. 1979. Reproductive patterns, p. 317-378. In: R.J. BaKer; J.K. Jones JR. \& D.C. CarTer (Eds). Biology of bats of the New World family Phyllostomatidae. Part III. Special Publications, Museum Texas Tech University, Lubbock, 16: 1-441.

Woodman, N.; R.M. Timm; R. Arana; V. Pacheco; C.A. Schmidt; E.D. Hooper \& C. Pacheco. 1991. Annotated checklist of the mammals of Cuzco Amazônico, Peru. Occasional Papers Museum of Natural History University of Kansas, Lawrence, 145: 1-12.

Yu, J. \& F.S. Dobson. 2000. Seven forms of rarity in mammals. Journal of Biogeography, Oxford, 27: 131-139.

Zortéa, M. \& A.G. Chiarello. 1994. Observations on the big fruit-eating bat, Artibeus lituratus, in an urban reserve of south-east Brazil. Mammalia, Paris, 58 (4): 665-670.

Received in 11.VI.2003; accepted in 12.XI.2003.

Revista Brasileira de Zoologia 20 (4): 691-697, dezembro 2003 